\title{
Brainstem auditory evoked potentials in horses
}

\author{
Potencial evocado auditivo de tronco encefálico em equinos
}

\author{
Juliana Almeida Nogueira da Gama' ${ }^{I}$ Mariana Isa Poci Palumbo ${ }^{I I}$ Giovane OlivoI \\ Nadia Crosignani Outeda ${ }^{\mathrm{I}}$ Luiz Antônio de Lima Resende ${ }^{\mathrm{III}}$ Alexandre Secorun Borges ${ }^{\mathrm{I}}$
}

\section{ABSTRACT}

The brainstem auditory evoked potential (BAEP) evaluates the integrity of the auditory pathways to the brainstem. The aim of this study was to evoke BAEPs in 21 clinically normal horses. The animals were sedated with detomidine hydrochloride $\left(0.013 \mathrm{mg} . \mathrm{kg}^{-1} \mathrm{BW}\right)$. Earphones were inserted and rarefaction clicks at $90 \mathrm{~dB}$ and noise masking at $40 \mathrm{~dB}$ were used. After performing the test, the latencies of waves $(I, I I, I I I, I V$, and $V)$ and interpeaks(I$I I I, I I I-V$, and $I-V)$ were identified. The mean latencies of the waves were as follows: wave I, $2.4 \mathrm{~ms}$; wave II, $2.24 \mathrm{~ms}$; wave III, 3.61 ms; wave $I V, 4.61 \mathrm{~ms}$; and wave $V, 5.49 \mathrm{~ms}$. The mean latencies of the interpeaks were as follows: I-III, $1.37 \mathrm{~ms}$; III-V, 1.88ms; and I-V, 3.26ms. This is the first study using BAEPs in horses in Brazil, and the observed latencies will be used as normative data for the interpretation of tests performed on horses with changes related to auditory system or neurologic abnormalities.

Key words: horses, interpeaks, latency, deafness.

\section{RESUMO}

O Potencial Evocado Auditivo de Tronco Encefálico (BAEP-Brainstem Auditory Evoked Potential) avalia a integridade das vias auditivas até o tronco encefálico. $O$ objetivo da pesquisa foi padronizar o uso do BAEP em 21 equinos, sem aparente anormalidade auditiva. Os animais foram sedados com cloridrato de detomidina $\left(0,013 \mathrm{mg} . \mathrm{kg}^{-1}\right.$ de PV). Foram utilizados fones de inserção, cliques de rarefação a $90 \mathrm{~dB}$ e um ruído de mascaramento de 40 dB. Foram identificadas as latências das ondas I, II, III, IV e Ve dos interpicos I-III, III-V e I-V. As médias das latências das ondas foram: onda I 2,24ms; onda II 2,74ms; onda III 3,61ms; onda IV 4,61ms; e onda V 5,49ms. As médias das latências dos interpicos foram: I-III 1,37ms; III-V 1,88ms; e I-V 3,26ms. Este é o primeiro estudo utilizando o BAEP em equinos no Brasil e as latências observadas serão utilizadas como dados normativos para interpretação de exames de cavalos com anormalidades auditivas ou neurológicas.

Palavras-chave: cavalos, interpicos, latência, surdez.

\section{INTRODUCTION}

Hearing is one of the primary means for interacting with the environment and is important for survival and perceiving other animals and possible predators (STRAIN \& MYERS, 2006). The brainstem auditory evoked potential (BAEP) is an objective test that evaluates the integrity of the auditory pathway. Interpretation of the results aids the veterinarian in diagnosing deafness and establishing the severity of the lesion in the auditory pathway (MAYHEW \& WASHBOURNE, 1990; STRAIN, 1996). When this test is performed in a healthy animal, a waveform with up to seven peaks can be observed. The first five peaks are the most clinically informative, and peaks I, III, and V are the easiest to identify at intensities ranging from 70 to $90 \mathrm{~dB}$ (MAYHEW \& WASHBOURNE, 1992).

Each wave produced corresponds to a specific region of the auditory pathway. Waves I, II, III, IV, and V originate in the ipsilateral cranial nerve VIII, cochlear nucleus, pons, lateral lemniscus, and caudal colliculus of the midbrain. Waves VI and VII are generated in the medial geniculate body of

\footnotetext{
'Universidade Estadual Paulista "Júlio de Mesquita Filho" (UNESP), Rubião Júnior, s/n, 18618-000, Botucatu, SP, Brasil. E-mail: asborges@fmvz.unesp.br. "Corresponding author.

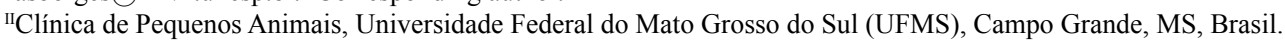

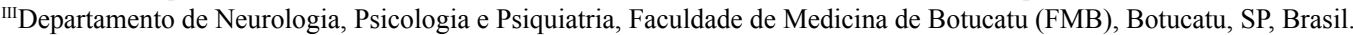
Received 11.25.14 Approved 08.31.15 Returned by the author 12.09.15 CR-2014-1716.R1
} 
the thalamus and auditory radiations. These latter two waves are not always present in horses (MAYHEW \& WASHBOURNE, 1997).

Use of BAEPs to assess the auditory function of horses has been studied since 1980 (MARSHALL, 1981, 1985). In addition to horses (ROLF et al., 1987; MAYHEW \& WASHBOURNE, 1997; MAYHEW, 2003; WILSON et al., 2011), similar studies have been conducted in human adults and children (JIANG et al., 1991), dogs (HOLLIDAY \& TE SELLE, 1985, KAWASAKI \& INADA, 1994; UZUKA et al., 1998; MURRELL et al., 2005; WILSON \& MILLS, 2005; PALUMBO et al., 2012), and cattle (ARAI, 2008).

The objective of this study was to standardize the BAEP in healthy horses in Brazil and characterize the latencies of the waves generated at a given intensity of an acoustic stimulus in 21 adult horses.

\section{MATERIALS AND METHODS}

Auditory evoked potential tests were performed in 21 horses, including 13 males and eight females, aging between two to 12 years. This study was conducted in the Electroneurodiagnostic Laboratory of the Department of Veterinary Clinical Sciences, School of Veterinary Medicine and Animal Science (Faculdade de MedicinaVeterinária e Zootecnia FMVZ), São Paulo State University (Universidade Estadual Paulista - UNESP) - Botucatu, and was initiated following approval by the Ethics Committee (protocol: 201/2012). As an animal selection criterion, an otoscopy was performed to confirm that the auditory canal and inner pinna were intact and had no alteration that could affect the test results.

The animals underwent a 12-h solidfood fast prior to the procedure. Animals were then intravenously sedated with detomidine hydrochloride (0.013mg.kg-1 BW). The test was initiated 10 minutes after sedation. Needle electrodes were inserted subcutaneously at the base of each ear (O1 and O2active electrodes), on the forehead (Fpz - reference electrode), and at the vertex $(\mathrm{Cz}$ - ground electrode) (Figure 1). A band-pass filter of $200-3000 \mathrm{~Hz}$, a sensitivity of $2.5 \mu \mathrm{Vcm}^{-1}$, and an analysis time of $1 \mathrm{~ms} /$ $\mathrm{cm}$ were used. Insert earphones were used to transmit the sound stimuli. Tests used rarefaction clicks with a duration of $2 \mathrm{~ms}$ and an intensity of $90 \mathrm{~dB}$ in the tested ear and a masking noise with an intensity of $40 \mathrm{~dB}$ in the contralateral ear. For each ear, at least two sets

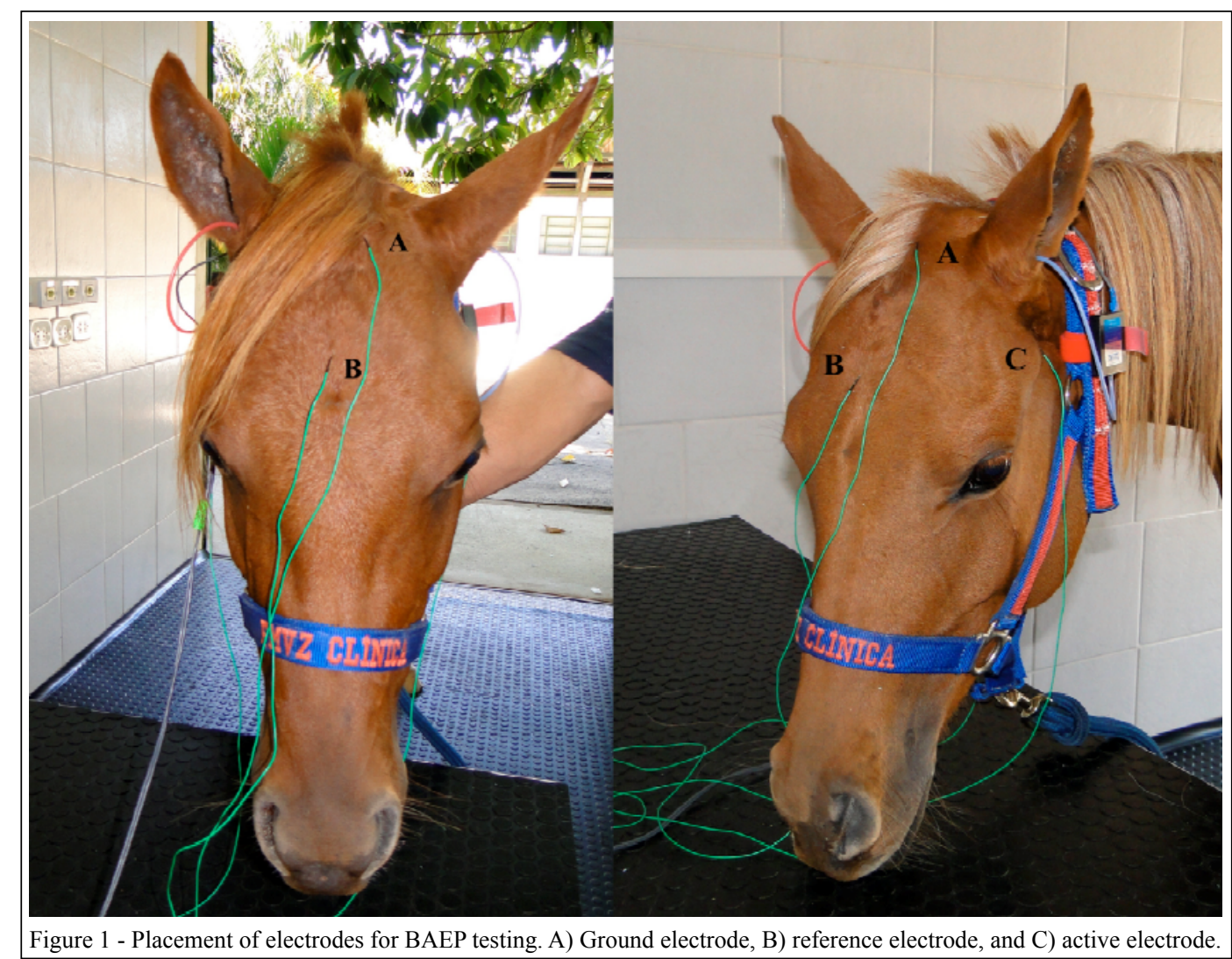

Ciência Rural, v.46, n.4, abr, 2016. 
of 500 stimuli were obtained using a 2-channel Teca Synergy System (Viasys Healthcare ${ }^{\circledR}$ ).

Each test measured the absolute latencies in milliseconds of waves I, III and V and of interpeaksIIII, III-V, and I-V on each side. These values were used to calculate and interpret the means and standard deviations of the variables. Values obtained from the right and left sides and those obtained from males and females were compared (paired t-test).

\section{RESULTS}

Figure 2 shows the auditory evoked potential obtained from an adult horse. Table 1 shows the mean, minimum, and maximum values and standard deviations of waves I, II, III, IV, and V and of interpeaks I-III, IIII-V, and I-V for the 21 animals at an intensity of $90 \mathrm{~dB}$.

There was no significant difference between the latency values obtained from the left and right sides of the animals. Except for wave III $(\mathrm{P}=0.0082)$, the remaining waves and interpeaks showed no statistically significant differences $(\mathrm{P} \geq 0.05)$ between males and females.

\section{DISCUSSION}

Despite the lack of previous reports of BAEP testing in horses in Brazil, this test has been used for various purposes in other countries. HARLAND et al. (2006) described the use of BAEP testing to diagnose deafness in a horse belonging to a Paint Horse breed that lacks pigmentation of the face and has blue eyes. In 2008, ALEMAN et al. used
BAEP testing to diagnose deafness in horses with temporohyoid osteoarthropathy (THO). ALEMAN et al. (2014a) identified auditory impairment in 57 horses after performing BAEP testing on 76 animals. The most common causes of BAEP changes were THO, congenital sensorineural deafness in Paint Horses, multifocal cerebral disease, and otitis media/ interna. ALEMAN et al. (2014b) associated changes in the potentials of foals with diseases such as sepsis, neonatal encephalopathy, neonatal isoerythrolysis, and preterm birth. Results of the present study will be used as a reference for comparison with the latencies obtained from horses with various alterations in their auditory pathways.

Latency values obtained in this study were similar to those obtained by ALEMAN et al. (2014): wave I, $2.12( \pm 0.06) \mathrm{ms}$; wave III, $3.61( \pm 0.17) \mathrm{ms}$; wave V, $5.36( \pm 0.16) \mathrm{ms}$; interpeak I-III, $1.40( \pm 0.15)$ $\mathrm{ms}$; interpeak III-V, $1.74( \pm 0.15) \mathrm{ms}$; and interpeak $\mathrm{I}-\mathrm{V}, 3.14( \pm 0.12) \mathrm{ms}$. In BAEP tests on horses, wave I required an additional $1.0 \mathrm{~ms}$ to travel through the earphones and reach the animal's ear compared to the results of other authors using headphones (MAYHEW \& WASHBOURNE, 1990, 1992, 1997; MAYHEW, 2003). This difference may be explained by the unqualified delay in the earphones compared to the use of headphones (MAYHEW \& WASHBOURNE, 1992).

Multiple factors can influence the variation of BAEP results, including age, sex, breed, and head size (WILSON \& MILLS, 2005). Animals with a larger head require a greater time to produce a response to the generated stimuli. Breed was not a criterion used to select the animals, and therefore, it was not investigated. In the present study, when the latencies

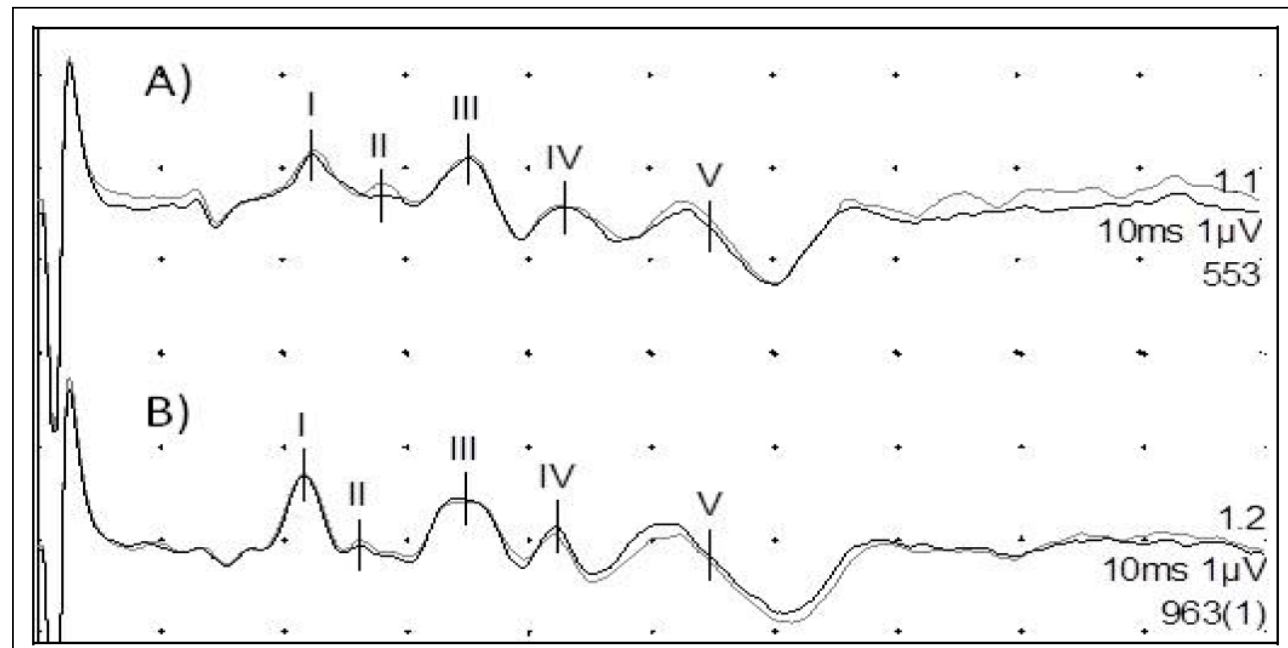

Figure 2 - BAEP of a healthy animal. A) Left side. B) Right side. Note the identification of waves I, II, III, IV, and $\mathrm{V}$ (vertical division: $1 \mu \mathrm{V}$; horizontal division: $1 \mathrm{~ms}$ ). 
Table 1 - Mean, minimum, and maximum values and standard deviations of the latencies of waves (I, II, III, IV, and $\mathrm{V})$ and interpeaks (I-III, III-V, and IV) at an intensity of $90 \mathrm{~dB}$ in 21 horses.

\begin{tabular}{lccc}
\hline Latency & Mean (ms) & $\begin{array}{c}\text { Minimum - } \\
\text { Maximum }(\mathrm{ms})\end{array}$ & Standard deviation \\
\hline I & 2.24 & $2.1-2.34$ & 0.06 \\
II & 2.74 & $2.58-2.92$ & 0.08 \\
III & 3.61 & $3.36-3.88$ & 0.12 \\
IV & 4.61 & $4.22-4.86$ & 0.17 \\
V & 5.49 & $5.24-5.92$ & 0.15 \\
I-III & 1.37 & $1.16-1.64$ & 0.11 \\
III-V & 1.88 & $1.46-2.18$ & 0.16 \\
I-V & 3.26 & $2.98-3.70$ & 0.16 \\
\hline
\end{tabular}

of males and females were compared, only wave III was significantly longer in males. As there was no significant difference in the remaining latencies, this increase may not have clinical relevance.

WILSON et al. (2011) described the use of BAEP testing for the diagnosis of deafness in older horses. Their study used nine horses, five young and four older horses. Stimulus intensities of 90 to $20 \mathrm{~dB}$ were used. When comparing the two groups, the older group of animals had worse hearing thresholds and wave $\mathrm{V}$ amplitudes at a stimulus intensity of $90 \mathrm{~dB}$. In the present study, animals aged between two and 12 years were selected so that age would not interfere with the obtained latencies, and the stimulus intensity was kept constant.

Some pharmaceuticals, such as aminoglycosides (CROWELL, 1981; NOSTRANDT, 1991), have toxic effects, affecting the hair cells of the cochlea and altering BAEP results. In this study, although the animals' previous history of medication use was unknown, none of the 21 tested horses showed any alteration in the tracings.

Some anesthetics can alter the latency and amplitude of the BAEP waves (WILSON \& MILLS, 2005); however, these drugs are used to facilitate the collection and interpretation of the results (POMIANOWSKI \& ADAMIAK, 2010). Detomidine was used for BAEP testing in horses by other authors without interfering with the results obtained (MAYHEW \& WASHBOURNE, 1990; MAYHEW \& WASHBOURNE, 1992; MAYHEW \& WASHBOURNE, 1997; HARLAND et al., 2006; WILSON et al., 2011). Because horses become agitated during handling of the ears and placement of the earphones, sedation enables the recording of potentials with less interference and produces less stress for the animals.

\section{CONCLUSION}

This is the first technical standardization study for horses in Brazil and is of great importance to the diagnosis of hearing disorders that have not been clinically identified.

\section{ACKNOWLEDGMENTS}

The authors are thankful forthe grant provided by the São Paulo Research Foundation (Fundação de Amparo à Pesquisa do Estado de São Paulo - FAPESP - 2010/00518-1).

\section{REFERÊNCIAS}

ALEMAN, M. et al. Brainstem auditory-evoked responses in horses with temporohyoidosteo arthropathy. Journal of Veterinary Internal Medicine, v.22, p.1196-1202, 2008. Available from: <http://onlinelibrary.wiley.com/doi/10.1111/ j.1939-1676.2008.0158.x/full>. Accessed: Jan. 20, 2012. doi: 10.1111/j.1939-1676.2008.0158.x.

ALEMAN, M. et al. Brainstem auditory evoked responses in an equine patient population: part I-adult horses. Journal of Veterinary Internal Medicine, v.28, n.13, p.1310-1317, 2014a. Available from: $<$ http://onlinelibrary.wiley.com/doi/10.1111/jvim.12379/full $>$. Accessed: Aug. 01, 2014. doi: 10.1111/jvim.12379.

ALEMAN, M. et al. Brainstem auditory evoked responses in an equine patient population. part II: foals. Journal of Veterinary Internal Medicine, v.28, n.13, p.1318-1324, 2014b. Available from: $\quad<$ http://onlinelibrary.wiley.com/doi/10.1111/jvim.12377/ full>. Accessed: Aug. 01, 2014. doi: 10.1111/jvim.12377.

ARAI, S. Brainstem auditory evoked potentials in cattle sedated with xylazine. Canadian Journal of Veterinary Research, v.72, p.287-290, 2008. Available from: <http://www.ncbi.nlm.nih.gov/ pmc/articles/PMC2327241/=>. Accessed: Aug. 01, 2012.

CROWELL, W.A. et al. Neomycin toxicosis in calves. American Journal of Veterinary Research, v.42. n.1, p.29-34, 1981. Available from: <http://europepmc.org/abstract/med/6111966>. Accessed: Aug. 01, 2012.

HARLAND, M. et al. Diagnosis of deafness in a horse by brainstem auditory evoked potential. Canadian Veterinary Journal, v.47, p.151154, 2006. Available from: <http:/www.ncbi.nlm.nih.gov/pmc/articles/ PMC1345730/pdf/cvj47pg151.pdf $>$. Accessed: Aug. 01, 2012.

HOLLIDAY, T.A.; TE SELLE, M.E. Brain stem auditory-evoked potentials of dogs: wave forms and effects of recording electrode positions. American Journal of Veterinary Research, v.46, p.845-851, 1985. Available from: <http://europepmc.org/abstract/ med/4014834>. Accessed: Aug. 01, 2012.

JIANG, Z.D. et al. Brainstem auditory evoked responses from birth to adulthood: Normative data of latency and interval. Hearing Research, v. 54, p.67-74, 1991. Available from: <http:// www.sciencedirect.com/science/article/pii/037859559190137X>. Accessed: Aug. 01, 2012. doi: 10.1016/0378-5955(91)90137-X.

KAWASAKI, Y.; INADA, S. Peaks of brainstem auditory evoked potentials in dogs. Veterinary Research Communications, 
v.18, p.383-396, 1994. Available from: <http://link.springer.com/ article/10.1007/BF01839289>. Accessed: Aug. 01, 2012. doi: 10.1007/BF01839289.

MARSHALL, A.E. Brain stem auditory evoked response in the non-anesthetized horse and pony. American Journal of Veterinary Research, v.46, p.1445-1450, 1985. Available from: <http:// europepmc.org/abstract/med/4026024>. Accessed: Aug. 01, 2012.

MARSHALL, A. et al. Brainstem auditory evoked response in the diagnosis of inner ear injury in the horse. Journal of the American Veterinary Medical Association, v.178, p.282-286, 1981. Available from: <http://europepmc.org/abstract/med/6971862>. Accessed: Aug. 01, 2012.

MAYHEW, I.G.; WASHBOURNE, J.R. A method of assessing auditory and brainstem function in horses. British Veterinary Journal, v.146, p.509-518, 1990. Available from: <http://www. sciencedirect.com/science/article/pii/0007193590900547>. Accessed: Aug. 01, 2012. doi: 10.1016/0007-1935(90)90054-7.

MAYHEW, I.G.; WASHBOURNE, J.R. Short latency auditory evoked potentials recorded from non-anaesthetized thoroughbred horses. British Veterinary Journal, v.148, p.315-327, 1992 Available from: <http://www.sciencedirect.com/science/ article/pii/000719359290084E $>$. Accessed: Aug. 01, 2012.doi: 10.1016/0007-1935(92)90084-E.

MAYHEW, I.G.; WASHBOURNE, J.R. Brainstem auditory evoked potentials in horses and ponies. Veterinary Journal v.153, p.107-113, 1997.Available from: <http://www.sciencedirect. com/science/article/pii/S1090023397800159>. Accessed: Aug. 01, 2012.doi:10.1016/S1090-0233(97)80015-9.

MAYHEW, I.G. The clinical utility of brainstem auditory evoked response testing in horses. Equine Veterinary Education, v.15, p.31-33, 2003. Available from: <http:// onlinelibrary.wiley.com/doi/10.1111/j.2042-3292.2003. tb00209.x/abstract $>$. Accessed: Aug. 01, 2012. doi: 10.1111/ j.2042-3292.2003.tb00209.x.

MURRELL, J.C.; HELLEBREKERS, L.J. Investigation of changes in the middle latency auditory evoked potential during anesthesia with sevoflurane in dogs. American Journal of Veterinary Research, v.66, n.7, p.1156-1161, 2005. Available from: <http:// avmajournals.avma.org/doi/abs/10.2460/ajvr.2005.66.1156>. Accessed: Aug. 01, 2012. doi: 10.2460/ajvr.2005.66.1156.
NOSTRANDT, A.C. et al. Ototoxic potential of gentamicin in ponies. American Journal of Veterinary Research, v.52, n.3, p.494-498, 1991. Available from: <http://europepmc.org/abstract/med/2035927>. Accessed: Aug. 01, 2012.

PALUMBO, M.I.P. et al. Auditory evoked potential to diagnose of bilateral deafness in two dogs. Ciência Rural, v.42, n.3, p.494-497, 2012. Available from: <http://www.scielo.br/pdf/cr/v42n3/a8112cr5679.pdf $>$. Accessed: Jan. 01, 2013.

POMIANOWSKI, A.; ADAMIAK, Z. Bone-conducted brainstem auditory evoked response in a dog with total bilateral ear canal ablation: a case report. VeterinarniMedicina, v.55, p.39-41, 2010. Available from: $<$ http://vri.cz/docs/vetmed/55-01-39.pdf >. Accessed: Aug. 01, 2012.

ROLF, S.L. et al. Auditory brain stem response testing in anesthetized horses. American Journal of Veterinary Research, v.48, p.910-914, 1987. Available from: <http://europepmc.org/abstract/med/3605806>. Accessed: Aug. 01, 2012.

STRAIN, G.M. Aetiology prevalence and diagnosis of deafness in dogs and cats. British Veterinary Journal, v.152, p.17-36, 1996 Available from: <http://www.sciencedirect.com/science/article/pii/ S0007193596800832>. Accessed: Aug. 01, 2012. doi: 10.1016/S00071935(96)80083-2.

STRAIN, G.M.; MYERS, L.J. Audição e equilíbrio. In: REECE, W. Dukesfisiologia dos animais domésticos I. 12. ed. Rio de Janeiro: Guanabara Koogan, 2006. p.793-804.

UZUKA, Y. et al. Brainstem auditory evoked responses elicited by toneburst stimuli in clinically normal dogs. Journal of Veterinary Internal Medicine, v.12, p.22-25, 1998. Available from: <http://onlinelibrary. wiley.com/doi/10.1111/j.1939-1676.1998.tb00492.x/abstract>. Accessed: Aug. 01, 2012. doi: 10.1111/j.1939-1676.1998.tb00492.x.

WILSON, W.J.; MILLS, P.C. Brainstem auditory-evoked response in dogs. American Journal of Veterinary Research, v.66, n.12, p.2177-2187, 2005. Available from: <http://avmajournals.avma.org/doi/ abs/10.2460/ajvr.2005.66.2177>. Accessed: Aug. 01, 2012. doi: 10.2460/ ajvr.2005.66.2177.

WILSON, W.J. et al. Use of BAER to identify loss of auditory function in older horses. Australian Veterinary Journal, v.89, n.3, p.73-76, 2011. Available from: <http://onlinelibrary.wiley.com/doi/10.1111/j.17510813.2010.00682.x/full>. Accessed: Aug. 01, 2012. doi: 10.1111/j.17510813.2010.00682.x. 